\title{
Exploring Selling Feature vs Selling Value Toward Saving At Islamic Bank
}

\author{
M. Ruslianor Maika \\ Perbankan Syariah \\ Universitas Muhammadiyah Sidoarjo \\ Sidoarjo, Indonesia \\ mr.maika@umsida.ac.id
}

\author{
Fitri Nur Latifah \\ Perbankan Syariah \\ Universitas Muhammadiyah Sidoarjo \\ Sidoarjo, Indonesia
}

\begin{abstract}
This research aims to explore selling feature versus selling value toward savings in Islamic Bank. Technology is one of the easies of giving additional features in a product. Even though the utilization patterns and religious tendencies are the factors that influence the use of savings in Islamic Bank, the feature can both make the product be excellent for the customers and tend to be useless as well for them. This method is a hidden interview that is conducted by mystery shoppers by addressing various questions in connection with the opening of saving account at Islamic Bank. The occurrence of savings' at Islamic Bank slow growth must be response by the initiative new-strategy. The intersection of the values of the saving and lending product will substitute with the new-competitive excellence in order to re-increase the savings growth. From selling feature to selling value will make transient advantage as the initiative new-strategy in order to increase the savings growth at Islamic Bank. The organization which is reluctant to create changes tends to be replaced by other institutions which have new-competitive excellence needed by the customers.
\end{abstract} Saving

Keywords-Selling feature; Selling value; Islamic bank;

\section{INTRODUCTION}

In this paper, we propose to shift selling of product from add-on technology feature of product to selling value of product. As we know, we can't sell the product only by look at the market needs, but we should make proposals to people [1]. The principles modern of management and its responsibility require on value creation of product [2]. To create value of product, innovator have had the set of value proposition benefits that should design to attract customers [3].

Moreover, the customers' schemata on the product is also one of decisive factors that influences them in buying a product [4]. Unfortunately, the Islamic banking tends to be more focused on the strategy namely observing, imitating, and modifying the conventional banking product to make savings product based on Islam [5]. The previous researches indicate that the customers' attraction point in using a product or a service is based on the product's salient or excellent feature as well as its capability [6];[7]. The integration of technology in various business industries is the rational about the existence of adding product's features [7];[8];[9], in which the result of the research in economics and market shows that the adding activities of product's features tend to increase the product capacity and its tractive power [10]. Its increase affects the product quality and the increase of the institution's income [11].

But the customer lifetime values move quickly and we don't know how long each relationship will be [12]. Not all customers are equal, but if you want to verify the value proposition expired of your product, you can figure out the revenue streams [12], [13], [14]. To increase their revenues, companies will also need to think differently about how they develop and introduce products [15];[16]. Some of the most successful and disruptive innovations stem from a company's ability to tap into demand from non-customers in its market category [17]. Disrupter should identify new things and turning them into new opportunities can have a destructive impact on an organization [18]. As we know, the nature of saving and lending product in Islamic bank product is interdependent each other. If lending revenue streams increased, the revenue sharing of saving product will increased.

\section{SAVING AT ISLAMIC BANK}

Theoretically, Islamic banking in Indonesia applies two levels of Mudharabah in which Islamic bank is functioned as an intermediated institution in financing activities acting as mudharib (pasiva) and as shahibul mal in financial-distributing activities [19].

Saving is one of financing forms in Islamic bank in which generally there are two types namely 1) forbidden saving based on Islamic principle which implements interest, and 2) unforbidden saving based on Islamic principle which implements Mudharabah and wadiah principle [20]. The notion of Mudharabah shows that customers act as shahibul mal or fund owner and the bank acts as mudharib or the financial manager. Customer's fund or shahibul mal is the stated-amount of modal in form of cash and not of debt. In addition, Wadiah is a saving which can be withdrew timelessly without any required shares but volunteered by the bank [21].

Saving deposit is a deposit that can be withdrawn based on specified requirements agreed in advance, but cannot be withdrawn using cheque and or other similar instruments [22]. Saving was split into two types of contract. First is Wadiah, is Goods or money custody between the owner and the entrusted party with the 
obligation of the entrusted party to return the goods or money at any time. Second is Mudharabah, partnership between the fund owner (shahibul maal) and fund manager (mudharib) by sharing the business profit according to the contract [22];[23].

Their feature and mechanism will see in the following Table 1.

TABLE 1. FEATURE AND MECHANISM OF SAVING PRODUCT

\begin{tabular}{|c|c|}
\hline Wadiah & Mudharabah \\
\hline $\begin{array}{l}\text { Bank shall act as the party } \\
\text { receiving the funds and } \\
\text { customer shall acts as the } \\
\text { party placing the funds; }\end{array}$ & $\begin{array}{l}\text { Bank shall act as the fund } \\
\text { manager (mudharib) and } \\
\text { customer shall act as the } \\
\text { fund owner (shahibul maal); }\end{array}$ \\
\hline $\begin{array}{l}\text { Bank may not make any } \\
\text { promise of return or bonus to } \\
\text { the customer; }\end{array}$ & $\begin{array}{l}\text { Revenue sharing method } \\
\text { shall be defined in } \\
\text { accordance with the ratio } \\
\text { agreed in advance; }\end{array}$ \\
\hline $\begin{array}{l}\text { Bank may charge customer } \\
\text { administration fee in the } \\
\text { form of expenses directly } \\
\text { related to the account } \\
\text { management fee such as } \\
\text { cheque book printing } \\
\text { expenses, stamp duty, } \\
\text { printing of transaction report } \\
\text { and balance statement, } \\
\text { opening and closing of } \\
\text { account; }\end{array}$ & $\begin{array}{l}\text { Bank may charge customer } \\
\text { administration fee in the } \\
\text { form of expenses directly } \\
\text { related to the account } \\
\text { management fee such as } \\
\text { cheque book printing } \\
\text { expenses, stamp duty, } \\
\text { printing of transaction report } \\
\text { and balance statement, } \\
\text { opening and closing of } \\
\text { account; and }\end{array}$ \\
\hline $\begin{array}{l}\text { Bank shall guarantee the } \\
\text { return of funds to the } \\
\text { customer; and }\end{array}$ & $\begin{array}{l}\text { Fund withdrawal } \\
\text { customer may only be } \\
\text { conducted based on the } \\
\text { agreed term; }\end{array}$ \\
\hline $\begin{array}{l}\text { Customer may withdraw the } \\
\text { fund at any time. }\end{array}$ & $\begin{array}{l}\text { Bank is not permitted to } \\
\text { reduce the ratio of } \\
\text { customer's profit without } \\
\text { any prior approval from the } \\
\text { customer. }\end{array}$ \\
\hline
\end{tabular}

\section{METHOD}

The researcher will investigate directly on how the technique of selling savings product in customer service of Islamic Bank. The research was conducted in three months start from October 2016 to January 2017. The object of this research was customer service of BRI Syariah (one of the best Islamic bank in digital services). The data collection and data analysis used mystery shopping method, where the 6 (six) mystery shoppers would open new saving accounts in BRI Syariah and doing mysterious interview sessions about the selling technique of savings in BRI Syariah.

\section{SELLing FEATURE}

It has been a viral to talk about Islamic bank and most people, including both the customers and the up-coming customers, will say there is no obvious difference between Islamic and conventional bank. Based on the phenomenon, it can be retracted that the focus of the development strategy in Islamic bank conducted by Finance Service Authority or OJK (Otoritas Jasa Keuangan) years 2015-2019 is to improve the understanding and consciousness of society about Islamic bank [24]. One cause that makes it essential to raise the factor is that the lower product's varieties and the inappropriate service viewed by the society [24]. It is undeniable that the development of Islamic bank's savings still adopts three principles namely observing, imitating, and modifying, hence generally, there is no added value, which is obviously different from each other product except only those in related segmentation to enhance product's varieties.

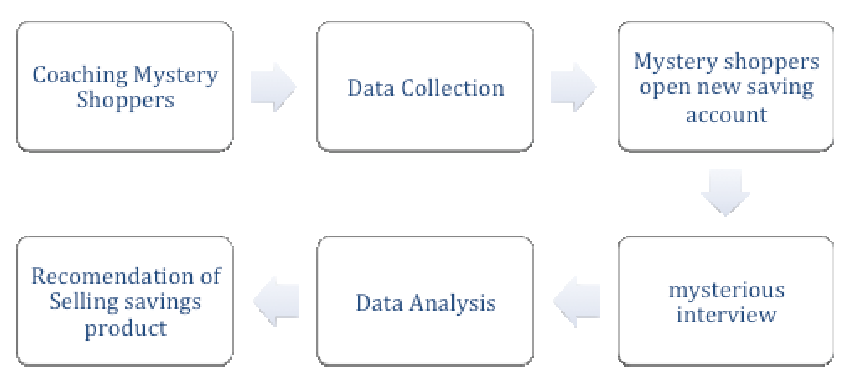

Fig. 1. Research process

The result of this study shows that the customer services were consistent in offering saving products, either Wadiah-based savings or Mudharabah-based ones. Whereas, customer were coming to Islamic Bank cannot choose but they want to see your proposal of product [25];[1]. Customers do not necessarily want a wide variety, but they do want what is exactly the right choice for them [26]. They also further explained about each product's features and mechanism such as facility, cost, and electronic-banking feature. More products seem to emphasize sophisticated simplicity rather than just a welter of features [26];[27];[28]

If we look the total numbers of Islamic Bank in Indonesia are about 13 and within the variation of saving types still cannot support savings product of Islamic bank to continually grow. The trend of the savings product increase in Indonesia Islamic bank keeps showing the annual increase within 2007-2015 period until 68,653 Mio in 2015. However, the data also shows that there is decreasing within the previous five years, 2011 to 2015 , for about $8 \%$, even there is a saving product increase in Islamic bank for about 36 trillion (2011-2015) (see figure 2) [29].

\section{Propose Selling Value}

The change of the strategy of selling the savings product is hopefully better to start as soon as possible in order to avoid the occurrence of decelerated saving growth. The change can be begun by switching the paradigm of feature selling for customers into the strategy of value selling. The difference of paradigm is based on the function of the product. The feature selling mostly exposes on the product capability with all features wile the value selling tends to be more on the customers' satisfactory. Hopefully, I does not only influence the customer's satisfactory but also to the revenues.

Feature selling is the description from various essential elements of a certain product offered by an institution by the hope of that customers are kindly attracted. In fact, feature 
selling does not have an intrinsic value. Even the benefits are obviously real for certain customers, but it is not futureimplicated for the others. For instance, in saving product at Islamic bank, customer service will explain the product features such as "for the minimum deposit feature in continuum is ten thousand rupiahs, the minimum balance is fifty thousand rupiahs, and the withdrawal activity in each day is five million rupiahs. Hence, the ATM can also be used at merchant, BRI, bersama and prima, but also applicable to merchant with the symbols of BRI Debit, BCA, Bersama and Prima”.

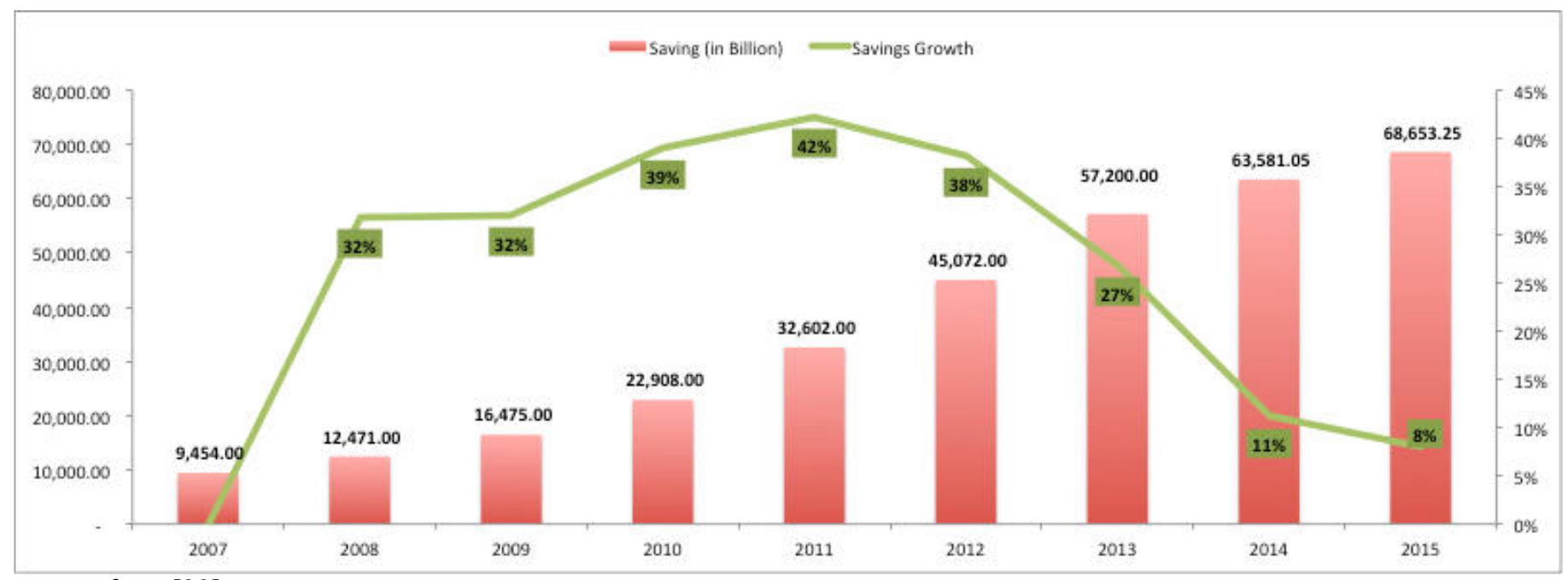

resume from [29]

Fig. 2. The growth of savings product of islamic bank in indonesia

Meanwhile, the selling value of a product is the core rational why customers want to move from one product to another, the function does not only solve the customers' problems, but also keeping them satisfied [13]. Moreover, customers also measure the values by evaluating the differences among all benefits and costs in using the product and other alternative products [30]. For instance, in offering a car with selling value "possible to decrease the overall mobile costs for $20 \%$ and broaden the periods of machine maintenance".

The result of the hidden interview done by 6 (six) mystery shoppers to two customer services in Islamic Bank showed that both customer services use selling feature method in saving products to their new applicants. When the mystery shoppers gave a question: "What is Faedah (name of product) savings?" the customer service generally answers that "Faedah saving is a type of saving product in which customers can withdraw the money in any sudden times". Afterwards, the mystery shoppers asked "what is the different between Faedah saving and the others?" the customer services tent to explain the various features, such as the minimum deposit, transfer cost, ATM facility, internet banking, the minimum balance, can be used in cash withdrawing in abroad, etc.

It is obvious that the knowledge of the customer service in Islamic Bank about savings which is only limited to product features and mechanism and unable to show the major excellent point of the product. This may become the result of the method of ATM (observing, imitating, and modifying). Hence, the selling value is important to build a product and indeed it can create a positive perspective toward the product.
Selling value in banking's product will be guaranteed by an economic approach. It means that value that is used to give to the customers and the new applicant covers finance scope. The idea is based on the function of intermediated bank, where the bank as an institution get the funds from societies and giving services to them as well as giving the funds in form of financing and servicing. Above function is in connection with finance, means that the parameter of the function of intermediated institution is the finance performance, if the performance of a certain bank is low, the savings product is either.

Why does the economics approach in finance become the most prior choice in the savings' selling value? It is because there is a relationship between it and the uniqueness of Islamic bank. Islamic bank has a different perspective compared to the conventional one in term of revenue sharing to the customers. Conventional bank with its interest principle gives the persistent interest even though the bank performance is in the best position, even in the worst one, so that the selling value of savings product delivered by its customer service is not related to the finance performance. Hence, it is absolutely different from the Islamic bank. In Islamic bank, Wadiah saving account gives the shares in form of bonus, which is paid to the customers, meaning that Islamic bank, with contract, is not bound to give the shares. While for the saving product with Mudharabah principle, customers will get the shares from the bank's company results done through the financial distribution to the deficitfinancial customers. The bigger the profit of the results of financial distribution, the bigger the shares got by the customers of the saving product.

It is clear that selling value of financial performance toward Islamic bank becomes unique that also be a rational 
for customers to move from the conventional bank. Different from the conventional one, selling feature is unique since in the conventional bank's saving product, there has been defined in form of bank interest once the customers open a new account. It has already proven that the excellent technology has by BCA recently is for the sake of selling feature mission which becomes the most salient strategy, even in other part, other administrative funds to support the feature are also expensive to pay.

This selling value model strategy is integrated with Resource Based View (RBV) approach. Hence it can happen competitive excellence for institution especially for Islamic Bank. RBV approach with the integration of funding and lending products can be the first prior to compete with institutions because it is the unique combination of resources owned by Islamic Bank. In designing product, it is necessary to consider the resource unique-criteria which fulfill VRIN; valuable, rare, imperfect imitability, non-substitutable, of each product, either funding or lending [31].

Restricted (muqayyadah) Mudharabah is one types of saving product that can implement in term of integration of funding and lending product. Restricted Mudharabah is a contract in which rabbul mal restricts the action of mudharib to a specified period or to a particular location or to a particular type of business that the rabbul mal considers appropriate, but not in a manner that would unduly constrain the mudharib in operation [32]. This saving product - with restricted mudharabah - requires great performance of lending product. If lending product booked heavy stream of revenues, absolutely Islamic Bank also post the highest revenue for sharing with customer savings.

Other concept is peer-to-peer (P2P) lending that is growing in financial technology sector. P2P lending is a decentralized model whereby two individuals interact to buy or sell goods and services directly with each other, without intermediation by a third-party, or without the use of a company of business. In term of savings product, Islamic bank may provide a system to enables individuals to borrow and lend money at the marketplace.

\section{CONCLUSION}

Selling value guarantees the competitive excellence which is relevant to VRIN, competitive advantage in an often-evaporated business industry within only less than a year. Company with dominant market tends to own a complete resource combination, but the company's external condition also cannot be handled well. To survive in further, a new initiative strategy is needed. If an organization cannot change the external changes, the competitive excellence will not be changed by the other competitive excellences that are not owned by the company but essentially needed by customers.

\section{REFERENCES}

[1] R. Verganti, Design-Driven Innovation, First eBoo. Harvard Business School Publishing Corporation, 2009.

[2] J. Magretta and N. Stone, What Management is?, 3rd editio. London: Profile Books, 2013.
[3] A. Osterwalder, Y. Pigneur, G. Bernarda, and A. Smith, Value Proposition Design, First edit. New Jersey: John Wiley \& Sons, Inc, 2014.

[4] N. Lin and B.-S. Lin, "The Effect of Brand Image and Product Knowledge on Purchase Intention Moderated by Price Discount," J. Int. Manag., vol. 2, no. August, pp. 121-132, 2007.

[5] M. K. Hassan, "Editorial," Int. J. Islam. Middle East. Financ. Manag., vol. 5, no. 4, Nov. 2012

[6] M. Rahman and M. M. Rahman, "To defeat feature fatigue the right way, understand it first," Strateg. Dir., vol. 25, no. 6, pp. 26-28, 2009

[7] N. Patel and D. K. Singh, "A Survey Based on Product Usability and Feature Fatigue Analysis Methods for Online Product," $J$. Eng. Comput. Appl. Sci., vol. 5, no. 8, pp. 53-57, 2016.

[8] D. V. Thompson, R. W. Hamilton, and R. T. Rust, "Feature Fatigue: When Product Capabilities Become Too Much of a Good Thing," J. Mark. Res., vol. XLII, no. November, pp. 431$442,2005$.

[9] M. R. Maika, "Model Ekonomi Berbagi 'Mobile-Seco' (Platform Multi-Sided Markets) Sebagai Ekosistem Sosio-Ekonomi Islami," Iqtishoduna, J. Ekon. dan Bisnis Islam, vol. 12, no. 2, pp. 47-55, 2016.

[10] M. Wu, L. Wang, H. Long, and M. Li, "Total Quality Management \& Business Excellence Feature fatigue analysis in product development," Total Qual. Manag., vol. 26, no. 2, pp. 218-232, 2015.

[11] G. Ellison, "A Model of Add-on Pricing," Q. J. Econ., vol. 120, no. 2, pp. 585-638, 2005.

[12] A. Gallo, "How Valuable Are Your Customers?," in Harvard Business Review, 2014, p. 6.

[13] A. Osterwalder and Y. Pigneur, Business Model Generation. New Jersey: John Wiley \& Sons, 2010.

[14] M. Schrage, "What Most Companies Miss About Customer Lifetime Value," 2017, no. April, p. 5.

[15] A. Bhattacharya, "How Digital is Redefining the Meaning of 'Products,"' linkedin, 2017. [Online]. Available: https://www.linkedin.com/pulse/how-digital-redefining-meaningproducts-arindam-

bhattacharya/?utm_source $=201710 \mathrm{Globalization \& utm \_ medium=}$ Email\&utm campaign $=$ otr. [Accessed: 13-Oct-2017].

[16] M. R. Maika, "Inovasi Model Bisnis Bank Muamalat Indonesia," perisai, vol. 1, no. 1, 2016.

[17] D. Fiore, "Implementing Innovation: Segment Your NonCustomers," Harvard Business Review, p. 3, Sep-2013.

[18] J. A. Schumpeter, Capitalism , Socialism and Democracy, EBook. Taylor \& Francis e-Library, 2003.

[19] Ascarya, "Akad dan Produk Bank Syariah: Konsep dan Praktek di Beberapa Negara," Bank Indonesia, Jakarta, 2006.

[20] Dewan Syari'ah Nasional, Fatwa Dewan Syariah Nasional: Tentang Tabungan. Indonesia: DSN-MUI, 2000, pp. 2-5.

[21] PKES, Perbankan Syariah. Jakarta: PKES Publishing, 2008.

[22] Directorate of Islamic Banking, "Codification of Islamic Banking Products," Jakarta, 2008.

[23] OJK, "Industri Jasa Keuangan Syariah," Jakarta, 2016.

[24] OJK, "Roadmap Perbankan Syariah Indonesia 2015-2019." Otoritas Jasa Keuangan, Jakarta, pp. 1-53, 2015.

[25] R. Verganti, "Design, meanings and radical innovation: A research agenda," J. Prod. Innov. Manag., vol. 25, no. 5, pp. 436-456, 2008.

[26] J. Utterback et al., Design-Inspired Innovation. Singapore: World Scientific Publishing Co. Pte. Ltd., 2006.

[27] T. Brown, Change By Design. Ideo.org, 2009.

[28] I. Mootee, Design Thinking for strategic innovation, 1st ed. New Jersey: John Wiley \& Sons, 2013.

[29] OJK, "Statistik Perbankan Syariah 2007-2015," Jakarta, 2015.

[30] P. Kotler and K. L. Keller, Marketing management, 14th ed. New Jersey: Pearson Education, 2006.

[31] H. Turino, Meretas Konsep Ekonomi Berbagi, 1st ed. Tangerang Selatan: PT Kesuma Putra Kreatif, 2016.

[32] A. G. Ismail, Money, Islamic Bank and the Real Economy, 1st editio. Singapore: Cengage Learning Asia Pte Ltd, 2010.

[33] R. Gunther McGrath, "Transient advantage," Harv. Bus. Rev., 
vol. 91, no. 6, pp. 1-10, 2013. 